\title{
Estimation of energy expenditure in free-living red deer (Cervus elaphus) with the doubly-labelled water method
}

\author{
P. Haggarty*, J. J. Robinson†, J. Ashton, E. Milne, C. L. Adam, C. E. Kyle, S. L. Christie \\ and A. J. Midwood $\neq$ \\ Rowett Research Institute, Greenburn Road, Bucksburn, Aberdeen AB21 9SB, UK
}

(Received 24 February 1998 - Revised 24 April 1998 - Accepted 29 April 1998)

\begin{abstract}
Energy expenditure was estimated using the doubly-labelled water (DLW) method in summer in five free-living adult, non-pregnant, non-lactating, red deer (Cervus elaphus) hinds (weight 107.3 (SE 0.9) kg; age 6 (SE 1) years) on lowland pasture under typical farming conditions. Climatic conditions were monitored throughout the experiment. Errors due to ${ }^{2} \mathrm{H}$ losses in $\mathrm{CH}_{4}$ and faeces were calculated from previous estimates of stoichiometries. $\mathrm{CH}_{4}$ production, fractionated water loss, urinary $\mathrm{N}$ and $\mathrm{O}_{2}$ consumption were estimated using an iterative approach. The water flux $\left(\mathrm{rH}_{2} \mathrm{O}\right)$ in these animals consuming only fresh grass was $12(\mathrm{SE} 0 \cdot 5) \mathrm{kg} / \mathrm{d}$, the $\mathrm{CO}_{2}$ production $\left(\mathrm{rCO}_{2}\right)$ was 1271 (SE 40) litres/d and the mean energy expenditure was 25 (SE 0.8) MJ/d. There were no significant differences in the isotope distribution spaces and flux rates, $\mathrm{rH}_{2} \mathrm{O}, \mathrm{rCO}_{2}$ or energy expenditure using the multi-point or two-point approaches to calculation. The DLWderived energy expenditure of $25 \mathrm{MJ} / \mathrm{d}$ is approximately $20 \%$ higher than the recommended intake of $21 \mathrm{MJ} / \mathrm{d}$ for adult hinds kept outdoors (Adam, 1986) and, at $757 \mathrm{~kJ} / \mathrm{kg}^{0.75} \mathrm{per} \mathrm{d}$, one third higher than the value of $570 \mathrm{~kJ} / \mathrm{kg}^{0.75}$ per $\mathrm{d}$ for stags penned indoors (Key et al. 1984).
\end{abstract}

Energy expenditure: Doubly-labelled water: Red deer

Energy is often the most important single factor in the nutrition of an animal. When natural diets meet the needs for energy, other essential nutrients (protein, fats, minerals and vitamins) will usually be supplied in amounts at least sufficient for survival (Kay et al. 1984). Knowledge of energy expenditure under typical free-living conditions is important when determining levels of feeding in production animals or in assessing the ecological impact of grazing in free-ranging animals. Animals such as red deer (Cervus elaphus) typically spend much of their life outdoors, even when farmed, and they may range over large areas. Traditional methods of estimating energy requirements, such as chamber calorimetry or even food-intake studies are therefore of limited use. The doubly-labelled water (DLW) technique (Lifson \& McClintock, 1966) is currently the most promising method of estimating energy expenditure in free-living animals. The DLW method has now been successfully validated in ruminant (Fancy et al. 1986; Midwood et al. 1994) and single-stomached (Haggarty et al. 1994a) production animals and may therefore be used with confidence in a wide variety of metabolic states if appropriate corrections are made for the processes which are known to introduce errors into the technique (Midwood et al. 1989; 1993; Haggarty, 1991; Haggarty et al. 1994a). In the present study, DLW was used to estimate the energy expenditure of adult non-pregnant red deer hinds in summer whilst on lowland pasture under typical farming conditions.

Energy expenditure may be calculated from DLW data using the two-point or multi-point methods, but the twopoint approach has the important advantage for studies in free-ranging animals that the samples of body fluids (typically blood) need only be taken on the first and last days of the labelling period and not each day as with the multi-point approach. Thus, one of the aims of the present study was to compare these two methods of calculation under typical experimental conditions.

In order to calculate water flux $\left(\mathrm{rH}_{2} \mathrm{O}\right)$ and $\mathrm{CO}_{2}$ production $\left(\mathrm{rCO}_{2}\right)$ it is necessary to correct the isotope flux data for fractionated water loss (Haggarty et al. 1988) and any change in pool size (Haggarty et al. 1994a) during the course of the labelling period. There are, however, other processes which may introduce errors into the DLW estimate of $\mathrm{rCO}_{2}$; for example, loss of ${ }^{2} \mathrm{H}$ into products other than water will cause $\mathrm{rH}_{2} \mathrm{O}$ to be overestimated and $\mathrm{rCO}_{2}$ to be underestimated. This may occur during sequestration of ${ }^{2} \mathrm{H}$ into stable $\mathrm{C}-\mathrm{H}$ bonds or by exchange of ${ }^{2} \mathrm{H}$ with labile

\footnotetext{
Abbreviations: DLW, doubly-labelled water; $\mathrm{rCO}_{2}, \mathrm{CO}_{2}$ production; $\mathrm{rH}_{2} \mathrm{O}$, water flux.

*Corresponding author: Dr Paul Haggarty, fax +44 (0) 1224 716629, email ph@ rri.sari.ac.uk

$†$ Present address: Scottish Agricultural College, Craibstone Estate, Bucksburn, Aberdeen AB21 9YA, UK.

$\$$ Present address: Macaulay Land Use Research Institute, Cragiebuckler, Aberdeen AB15 8QH, UK.
} 
positions on material which is subsequently exported from the body; faeces for example. The sequestration and exchange processes which have the potential to introduce substantial errors into the DLW method in production animals are: fat synthesis, $\mathrm{CH}_{4}$ production and export of faecal DM (Midwood et al. 1989; Haggarty, 1991; Haggarty et al. 1994a). The magnitude of these processes must be estimated in order to make the necessary corrections to the isotope flux data (Haggarty, 1991). Under the highly controlled conditions of a validation study it is possible to make direct measurements of faecal losses, $\mathrm{CH}_{4}$ production and even fat synthesis, but the need to carry out such measurements in a typical DLW study would largely nullify the main advantage of the DLW method which is that it can be used in free-living animals in their natural environment. The final aim of this study was to develop a method of correcting for the processes mentioned without the need to measure them directly, using only the data which are typically obtained in DLW studies in truly free-living animals.

\section{Materials and methods}

\section{Animals}

Seven adult (age 6.6 (SE 0.5) years), non-pregnant, nonlactating, red deer hinds (weight 103 (SE 2) kg) were studied. Five of the animals were dosed with triply-labelled $\left({ }^{2} \mathrm{H},{ }^{3} \mathrm{H},{ }^{18} \mathrm{O}\right)$ water at the beginning of the study period. The two remaining animals were used as controls to quantify any re-uptake of isotope excreted by the labelled animals. Before and during the experiment, the labelled and control animals were maintained together in a lowland field $(30 \mathrm{~m} \times 110 \mathrm{~m})$. Animals consumed only the grass in the field and were not provided with any additional feed. The experiment was carried out in the month of August in Aberdeen and climatic conditions were measured in the paddock where the animals were kept.

Samples of grass (approximately $1 \mathrm{~kg}$ per sample) were taken from the field on each day of the study and the chemical composition of the pooled sample was analysed. The grass consisted of $(\mathrm{g} / \mathrm{kg}): 590$ carbohydrate (polysaccharide equivalents), 150 protein and 64.9 lipid on a dry-weight basis. The energy content of the grass was estimated by bomb calorimetry at $17.389 \mathrm{~kJ} / \mathrm{g}$ dry weight. The DM content of the grass was $0.1935 \mathrm{~g} / \mathrm{g}$ wet weight.

At 10.00 hours on the first experimental day a catheter was inserted temporarily in the jugular vein. A blood sample was taken from each of the seven animals to determine the natural abundance of ${ }^{2} \mathrm{H}$ and ${ }^{18} \mathrm{O}$ in the body water before dosing. The labelled water (approximately $60 \mathrm{ml}$ ) was then administered to five of the deer as a sterile saline solution via the catheter. At 15.00 hours a second blood sample $(10 \mathrm{ml})$ was taken and further blood samples were taken daily by vacutainer for the next $10 \mathrm{~d}$ from the labelled deer and two control deer. Animals were restrained singly for the administration of dose and blood sampling. Body weight was determined at the beginning and end of the $10 \mathrm{~d}$ experimental period. Blood samples were centrifuged to separate the plasma which was then centrifuged through ultramembrane filters (Anachem,
Luton, Beds., UK) to remove any large molecular mass (> $30000 \mathrm{Da}$ ) compounds.

\section{Isotope analysis}

Sufficient isotope was administered to raise the ${ }^{2} \mathrm{H}$ and ${ }^{18} \mathrm{O}$ concentrations in the body water to approximately 160 and 200 parts per million ( $\mathrm{ppm})$ excess respectively $(0 \cdot 12 \mathrm{~g}$ $\mathrm{H}_{2}{ }^{18} \mathrm{O} / \mathrm{kg}$ body weight; $0 \cdot 16 \mathrm{~g}{ }^{2} \mathrm{H}_{2} \mathrm{O} / \mathrm{kg}$ body weight) and the ${ }^{3} \mathrm{H}$ to 45000 disintegrations/min per ml plasma. All stable isotope enrichments were determined on SIRA-10 and SIRA-12 dual-inlet isotope ratio mass spectrometers (VG, Middlewich, Ches., UK) relative to a series of laboratory reference waters previously calibrated against Vienna standard mean ocean water and standard light Antarctic precipitation. The ${ }^{18} \mathrm{O}$ content of the filtered plasma samples was determined by equilibration with $\mathrm{CO}_{2}$ in vacutainers (Midwood et al. 1992) and ${ }^{2} \mathrm{H}$ by $\mathrm{Zn}$ reduction of water (Wong et al. 1987) with the modification that $500 \mathrm{mg} \mathrm{Zn}$ was used for each reduction. The mean standard error for mass spectrometer analysis was $0 \cdot 2-0 \cdot 4 \mathrm{ppm}$ for ${ }^{2} \mathrm{H}$ and $0 \cdot 1-0 \cdot 2 \mathrm{ppm}$ for ${ }^{18} \mathrm{O}$. The ${ }^{3} \mathrm{H}$ was determined by liquid scintillation counting.

\section{Calculations}

Curve fitting was carried out using Maximum Likelihood Program (MLP, Numerical Algorithms Group, Oxford, Oxon, UK). A generalized linear model was fitted to the data with a logarithmic link function and poisson-type error (a heterogeneity factor was calculated from the residual mean deviation) as described elsewhere (Haggarty et al. 1994a). The intercepts and rate constants were derived from the fitted parameters. The flux rates, pool sizes, correction for changing pool size and faecal losses and the overall precision of the DLW method were calculated as described previously (Haggarty et al. 1994a).

In order to calculate $\mathrm{rCO}_{2}$ from ${ }^{2} \mathrm{H}$ and ${ }^{18} \mathrm{O}$ flux rates it is necessary to correct the isotope flux data for fractionated water loss, any change in pool size during the course of the labelling period and loss of ${ }^{2} \mathrm{H}$ into products other than water (Fig. 1). Furthermore, the DLW method only provides an estimate for $\mathrm{rCO}_{2}$, therefore additional information on $\mathrm{O}_{2}$ consumption, $\mathrm{N}$ loss and, in the case of ruminants, $\mathrm{CH}_{4}$ production, is required to calculate a value for energy expenditure. In the absence of direct measurements, the estimation of many of the correction factors and additional parameters depends on knowledge of the others before each can be calculated. We have proposed here an approach to the calculation where, after an initial approximation, each parameter is repeatedly calculated until there is no change with further iteration. Initially, the $\mathrm{N}$ loss, $\mathrm{rH}_{2} \mathrm{O}_{\text {(methane) }}, \mathrm{rH}_{2} \mathrm{O}_{\text {(faeces) }}, \mathrm{rO}_{2 \text { (methane) }}$ and $\mathrm{rCO}_{2 \text { (methane) }}$ were all set to zero and the following values ascribed to fractionation and the RQ: $\mathrm{f} 1=0.941, \mathrm{f} 2=0.99, \mathrm{f} 3=1 \cdot 039$, $\mathrm{X}=0 \cdot 1, \mathrm{RQ}=0 \cdot 94$ (estimated from the composition of the diet). The interconnections between the various parameters used in the iteration model are given in Fig. 2. The ${ }^{18} \mathrm{O}$ and ${ }^{2} \mathrm{H}$ flux rates were held constant whilst the other parameters in the illustration were allowed to vary. All other 

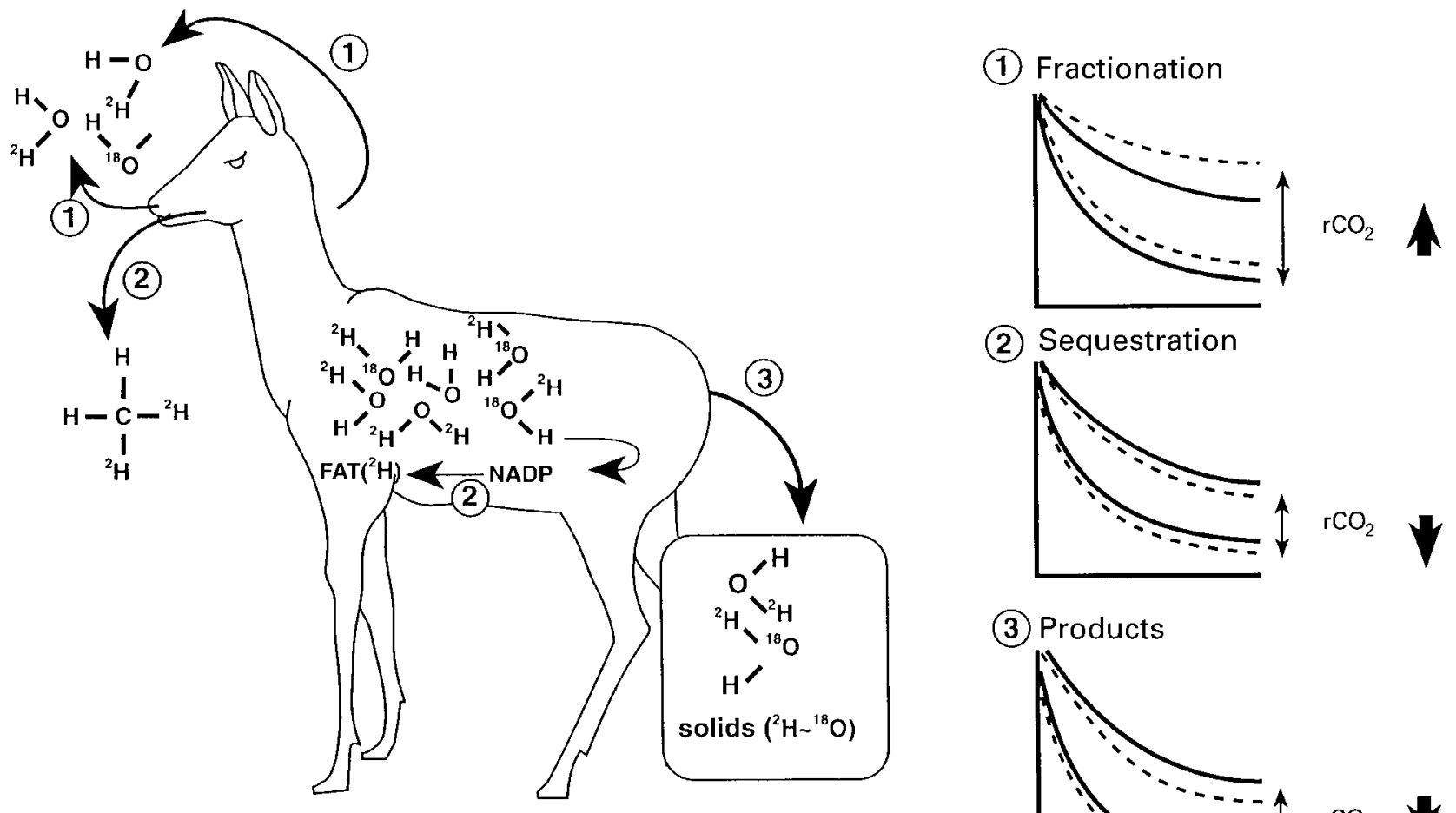

(2) Sequestration

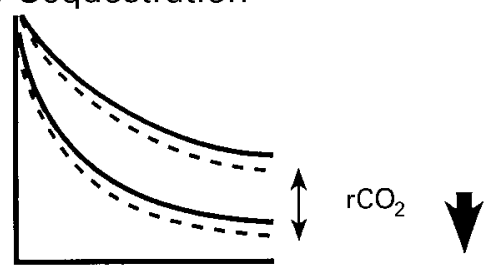

(3) Products

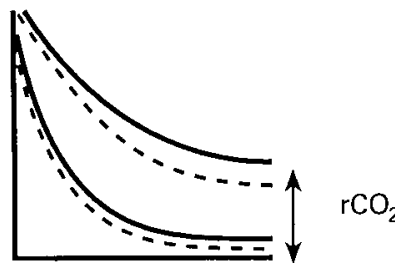

Fig. 1. The main factors which affect the calculation of water flux $\left(\mathrm{rH}_{2} \mathrm{O}\right)$ and $\mathrm{CO}_{2}$ production $\left(\mathrm{rCO}_{2}\right)$ from ${ }^{2} \mathrm{H}$ and ${ }^{18} \mathrm{O}$ flux rates are: (1) fractionation during evaporative water loss, (2) sequestration of ${ }^{2} \mathrm{H}$ into $\mathrm{CH}_{4}$ and body fat, (3) loss of ${ }^{2} \mathrm{H}$ and ${ }^{18} \mathrm{O}$ in sequestered and exchangeable positions in faecal solids. The effects of these processes (- - - ) on typical isotope decay curves (- - , where the upper line represents ${ }^{2} \mathrm{H}$ and the lower ${ }^{18} \mathrm{O}$, are shown, together with the effect on the calculation of $\mathrm{rCO}_{2}$. Fractionation has a larger effect on ${ }^{2} \mathrm{H}$ than ${ }^{18} \mathrm{O}$, therefore it is retained longer in the body and the difference in ${ }^{2} \mathrm{H}$ and ${ }^{18} \mathrm{O}$ flux rates is increased, resulting in an overestimate of $\mathrm{rCO}_{2}$ if not corrected for. Similarly, the rate of sequestration and loss of isotope in products are more pronounced for ${ }^{2} \mathrm{H}$, resulting in an increased rate of washout and an underestimate of $\mathrm{rCO}_{2}$ if not corrected for.

parameters and stoichiometries used in the model were held constant. Water flux $\left(\mathrm{rH}_{2} \mathrm{O} ; \mathrm{g} / \mathrm{d}\right)$ was calculated from the deuterium flux rate $\left({ }^{2} \mathrm{H}\right.$ flux; $\left.\mathrm{g} / \mathrm{d}\right)$ and water equivalents lost in $\mathrm{CH}_{4}$ and faeces $(\mathrm{g} / \mathrm{d})$ :

$\mathrm{rH}_{2} \mathrm{O}=\frac{{ }^{2} \mathrm{H} \text { flux }}{(\mathrm{f} 1 \times \mathrm{X})+(1-\mathrm{X})}-\left(\mathrm{rH}_{2} \mathrm{O}_{(\text {methane })}+\mathrm{rH}_{2} \mathrm{O}_{(\text {faeces })}\right)$.

$\mathrm{CO}_{2}$ production $\left(\mathrm{rCO}_{2} ; \mathrm{mol} / \mathrm{d}\right)$ was calculated from isotope flux rates $\left({ }^{18} \mathrm{O}\right.$ flux, ${ }^{2} \mathrm{H}$ flux; mol/d):

$$
\mathrm{rCO}_{2}=\frac{{ }^{18} \mathrm{O} \text { flux }-\left[\left(\mathrm{f} 2 \times \mathrm{X} \times \mathrm{rH}_{2} \mathrm{O}\right)+(1-\mathrm{X}) \times \mathrm{rH}_{2} \mathrm{O}\right]}{2 \times \mathrm{f} 3} .
$$

$\mathrm{CH}_{4}$ production $\left(\mathrm{rCH}_{4}\right.$; litres/d) was calculated from $\mathrm{rCO}_{2}$ (litres/d) and the ratio $\mathrm{rCH}_{4}: \mathrm{rCO}_{2}$ :

$$
\mathrm{rCH}_{4}=\mathrm{rCO}_{2} \times \text { ratio } \mathrm{CH}_{4}: \mathrm{CO}_{2} \text {. }
$$

$\mathrm{O}_{2}$ consumption $\left(\mathrm{rO}_{2}\right.$; litres/d) was calculated from $\mathrm{rCH}_{4}$ and $\mathrm{rCO}_{2}$ (both litres/d) and the RQ (0.941) estimated from the composition of the diet after correction for the $\mathrm{CO}_{2}$ equivalents consumed $\left(\mathrm{rCO}_{2 \text { (methane) }} ; 1\right.$ litre/litre $\left.\mathrm{rCH}_{4}\right)$ and $\mathrm{O}_{2}$ equivalents produced $\left(\mathrm{rO}_{2 \text { (methane) }} ; 2\right.$ litres/litre $\mathrm{rCH}_{4}$ ) during $\mathrm{CH}_{4}$ production:

$$
\mathrm{rO}_{2}=\frac{\mathrm{rCO}_{2}+\mathrm{rCO}_{2 \text { (methane) }}}{\mathrm{RQ}}-\mathrm{rO}_{2 \text { (methane) }} \text {. }
$$

Energy expenditure $(\mathrm{EE} ; \mathrm{kJ} / \mathrm{d})$ was calculated from $\mathrm{rO}_{2}$ $\mathrm{rCH}_{4}, \mathrm{rCO}_{2}$ (all litres/d) and $\mathrm{N}$ loss $(\mathrm{g} / \mathrm{d})$ :

$$
\begin{aligned}
\mathrm{EE}= & 16 \cdot 18 \times \mathrm{rO}_{2}+5 \cdot 02 \times \mathrm{rCO}_{2} \\
& -2 \cdot 17 \times \mathrm{rCH}_{4}-5.99 \times \mathrm{N} \text { loss. }
\end{aligned}
$$

Urinary $\mathrm{N}$ loss was calculated from energy expenditure, the digestible energy content of the diet $(\mathrm{kJ} / \mathrm{g})$, the digestibility of the diet and the $\mathrm{N}$ content of the diet $(\mathrm{g} / \mathrm{g}$ DM):

$\mathrm{N}$ loss $=\mathrm{EE} \times$ digestible energy $\times$ digestibility $\times \mathrm{N}$ in diet.

Evaporative water loss $(\mathrm{g} / \mathrm{d})$ was calculated from energy expenditure $(\mathrm{kJ} / \mathrm{d})$, the proportion of heat lost evaporatively and the latent heat of evaporation of water at $33^{\circ}(\mathrm{kJ} / \mathrm{g})$ :

evaporative water loss

$$
=\frac{\mathrm{EE} \times \text { proportion of heat lost evaporatively }}{\text { latent heat of evaporation }} .
$$

The proportion of water loss which undergoes fractionation 


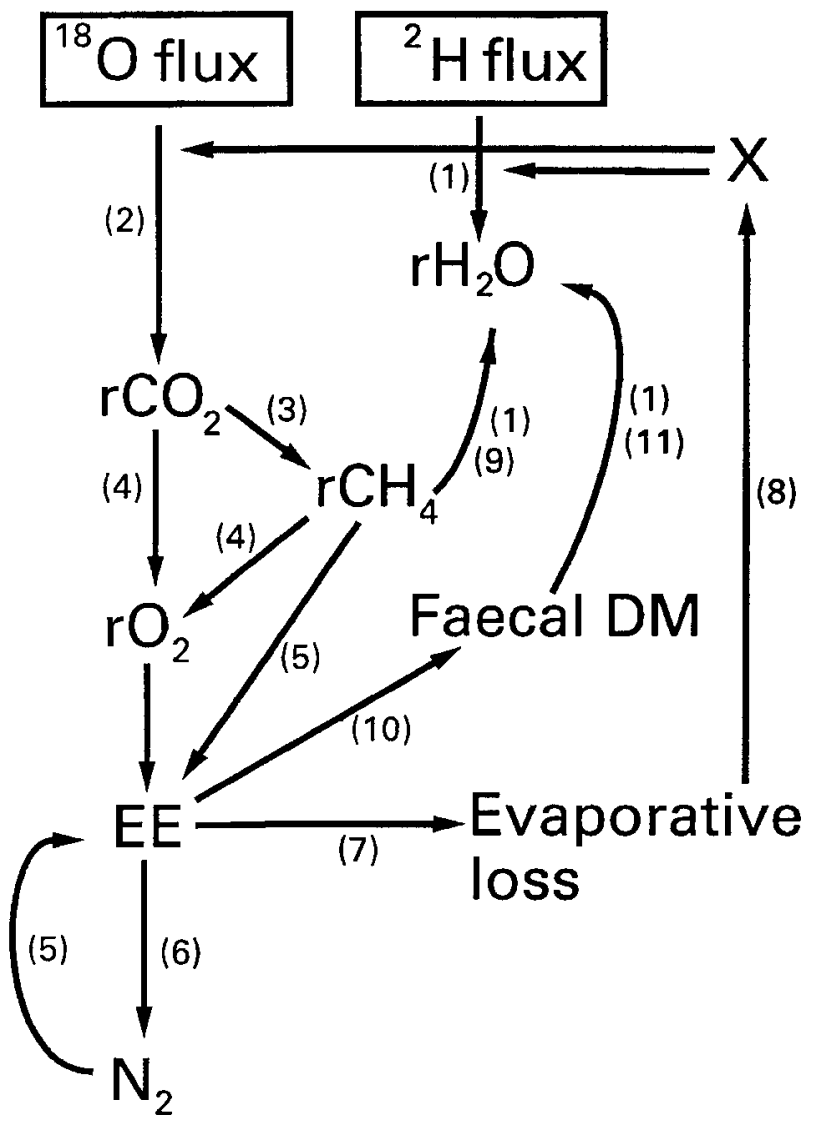

Fig. 2. The interconnections between the various parameters which are allowed to vary in the iteration model are shown here together with the relevant equation number (in brackets) in the text defining the relationship. The only parameters in this illustration which are not allowed to vary are the ${ }^{18} \mathrm{O}$ flux and the ${ }^{2} \mathrm{H}$ flux. EE, energy expenditure; $\mathrm{rCH}_{4}, \mathrm{CH}_{4}$ production; $\mathrm{rCO}_{2}, \mathrm{CO}_{2}$ production; $\mathrm{rO}_{2}, \mathrm{O}_{2}$ consumption; $\mathrm{rH}_{2} \mathrm{O}$, water flux; $\mathrm{X}$, fractionated water loss.

(X) was calculated from the total evaporative water loss (g) and $\mathrm{rH}_{2} \mathrm{O}(\mathrm{g})$ :

$$
\mathrm{X}=\frac{\text { evaporative water loss }}{\mathrm{rH}_{2} \mathrm{O}} .
$$

The water equivalents lost in $\mathrm{CH}_{4}\left(\mathrm{rH}_{2} \mathrm{O}_{\text {(methane) }}\right.$; g/d) were calculated from $\mathrm{rCH}_{4}$ (litres) and the stoichiometry of $\mathrm{CH}_{4}$ to water loss $(\mathrm{g} / \mathrm{l})$ :

$\mathrm{rH}_{2} \mathrm{O}_{\text {(methane) }}=\mathrm{rCH}_{4} \times$ stoichiometry of $\mathrm{CH}_{4}$ to water loss.

Faecal DM production $(\mathrm{g} / \mathrm{d})$ was calculated from energy expenditure, the digestible energy content of the diet $(\mathrm{kJ} / \mathrm{g}$ DM) and the digestibility of the diet:

faecal $\mathrm{DM}=(\mathrm{EE} \times$ digestible energy $) \times(1-$ digestibility $)$.

The water equivalents lost in faeces $\left(\mathrm{rH}_{2} \mathrm{O}_{\text {(faeces) }} ; \mathrm{g} / \mathrm{d}\right)$ were calculated from $\mathrm{rCH}_{4}$ (litres/d) and the stoichiometry of DM to water loss:

$$
\begin{aligned}
\mathrm{rH}_{2} \mathrm{O}_{\text {(faeces) }}= & \text { faecal DM } \\
& \times \text { stoichiometry of faecal DM to water loss. }
\end{aligned}
$$

\section{Results and discussion}

The average age of the five experimental deer dosed with labelled water was 6 (SE 1) years (Table 1). The age of both the control animals was 8 years. The average body weight of the experimental group was 107 (SE 0.9) kg whilst that of the control animals was $94 \mathrm{~kg}$. During the course of the $10 \mathrm{~d}$ experimental period, animals B and C lost weight whilst animals D and $\mathrm{E}$ gained weight; there was no change in the body weight of animal A. However, the change in each animal was small and could be accounted for by normal variations in gut fill and the mean weight change was not significant $(-0 \cdot 2($ SE $0 \cdot 7) \mathrm{kg})$. It is therefore unlikely that the deer were depositing body fat during the course of the DLW experiment. However, even in the absence of net fat deposition it is still possible that fat turnover could in theory result in water ${ }^{2} \mathrm{H}$ sequestration. We have previously determined that the sequestration of ${ }^{2} \mathrm{H}$ into body fat has an insignificant effect on the DLW method in singlestomached and ruminant species in approximate weight balance (Haggarty, 1990; Midwood et al. 1993). Therefore, ${ }^{2} \mathrm{H}$ sequestration into body fat was considered to have a negligible effect on the accuracy of the DLW method in the deer studied here.

During the $10 \mathrm{~d}$ DLW period the climatic conditions (Table 2) were typical of the area for the summer month of August.

There was no significant increase in the concentration of ${ }^{2} \mathrm{H},{ }^{3} \mathrm{H}$ or ${ }^{18} \mathrm{O}$ in the body water of the two unlabelled deer sharing the same field with the labelled animals. It was, therefore, assumed that there was no significant re-uptake of isotope from the environment by the labelled animals.

A number of calculation procedures may be used to estimate $\mathrm{rH}_{2} \mathrm{O}$ and $\mathrm{rCO}_{2}$ in a DLW study and may be categorized by the number of data points used. (a) The two-point calculation procedure, originally proposed by Lifson \& McClintock (1966) for use in small mammals, relies on two post-dose samples, one taken at the start of the experiment, after the isotope dose has been allowed to equilibrate but before it has been significantly diluted by ingested water (usually $2-9 \mathrm{~h}$ after dosing), and another taken at the end of the experimental period; usually two or three biological half-lives. The isotope dilution spaces are calculated from the increase in body water enrichment after equilibration and the rate constants calculated as the gradient between the $\log _{\mathrm{e}}$ of the excess enrichment of the first and last data points. (b) Flux rates may also be calculated using the multi-point approach which involves collecting a series of samples (typically daily) throughout the study. An exponential model is then fitted to the data yielding a value of the extrapolated intercept (used to calculate the isotope distribution space) and rate constant for each isotope (see e.g. Midwood et al. 1994). Both the two-point and 
Table 1. Details of the red deer used as experimental and control animals

\begin{tabular}{|c|c|c|c|c|c|c|c|c|c|}
\hline & \multicolumn{7}{|c|}{ Experimental deer } & \multicolumn{2}{|c|}{ Control deer } \\
\hline $\begin{array}{l}\text { Age (years) } \\
\text { Starting weight }(\mathrm{kg}) \\
\text { Weight change }(\mathrm{kg} / 10 \mathrm{~d})\end{array}$ & $\begin{array}{r}8 \\
104 \cdot 5 \\
0.0\end{array}$ & $\begin{array}{c}7 \\
109 \cdot 5 \\
-2 \cdot 0\end{array}$ & $\begin{array}{r}7 \\
107.5 \\
-1.5\end{array}$ & $\begin{array}{r}6 \\
106 \cdot 5 \\
1 \cdot 0\end{array}$ & $\begin{array}{r}4 \\
108 \cdot 5 \\
1.5\end{array}$ & $\begin{array}{c}6 \\
107 \cdot 3 \\
-0 \cdot 2\end{array}$ & $\begin{array}{l}1 \\
0 \cdot 9 \\
0 \cdot 7\end{array}$ & $\begin{array}{c}8 \\
94 \cdot 5\end{array}$ & $\begin{array}{c}8 \\
94.0\end{array}$ \\
\hline
\end{tabular}

multi-point approaches also require a sample to be taken immediately before dosing for the estimation of the natural or background abundance of ${ }^{2} \mathrm{H}$ and ${ }^{18} \mathrm{O}$ in the body water. The results of these two different approaches to estimating the isotope dilution space and body composition are presented in Table 3. There was no difference in the ${ }^{2} \mathrm{H}:{ }^{18} \mathrm{O}$ dilution space ratio $(1.024$ (SE 0.004) for the multi-point method and 1.025 (SE 0.004) for the two-point method), or the individual isotope dilution spaces $\left(\mathrm{N}^{2} \mathrm{H}, 70 \cdot 45\right.$ (SE 0.81) and $\mathrm{N}^{18} \mathrm{O}, 68.78$ (SE 0.91$) \mathrm{kg}$ for the multi-point and $\mathrm{N}^{2} \mathrm{H}, 70.95$ (SE 0.65) and $\mathrm{N}^{18} \mathrm{O}, 69 \cdot 21$ (SE 0.83) $\mathrm{kg}$ for the two-point method). The isotope dilution spaces may also be used to estimate body water from the relationship between isotope dilution space and body water. The derived estimates of body water were 68.10 (SE 0.90) $\mathrm{kg}$ for the multi-point method and 68.53 (SE 0.83) $\mathrm{kg}$ for the two-point method; again these values were not significantly different.

Water balance can be used to determine total evaporative water loss, but this will usually overestimate fractionated water loss in sweating species because it contains some evaporated but unfractionated sweat loss (Haggarty et al. 1988). However, Johnson et al. (1972), who measured sweat gland function in the red deer, found rates of water loss at an ambient temperature of $20^{\circ}$ which were within the range observed in sheep and human subjects with a congenital absence of sweat glands. These authors concluded that even at $20^{\circ}$, a temperature exceeding the maximum of $16^{\circ}$ achieved during this free-living study, it is unlikely that red deer lose water by active sweating. Under these circumstances total evaporative water loss may be used as an index of fractionated water loss. Brockway \& Maloiy (1967) found that at $18^{\circ}$ approximately $50 \%$ of the heat loss from red deer was by evaporation. The latent heat of evaporation of water at $33^{\circ}$ is $2418 \mathrm{~J} / \mathrm{g}$ (Blaxter, 1989), therefore water loss can be estimated from energy expenditure. However, a problem arises because the value for fractionated water loss is required to calculate $\mathrm{rCO}_{2}$ and energy expenditure. This circular problem can be overcome using an iterative approach (Haggarty et al. 1994b) whereby the raw isotope flux rates (uncorrected for fractionated water loss) are used

Table 2. Average environmental conditions during the doublylabelled water study

\begin{tabular}{lr}
\hline Wind speed (knots) & $8 \cdot 7$ \\
Rainfall $(\mathrm{mm} / \mathrm{d})$ & $3 \cdot 3$ \\
Sunshine $(\mathrm{h} / \mathrm{d})$ & $4 \cdot 5$ \\
Maximum temperature $\left({ }^{\circ}\right)$ & $16 \cdot 6$ \\
Minimum temperature $\left(^{\circ}\right)$ & $9 \cdot 5$ \\
Relative humidity $(\%)$ & 85 \\
\hline
\end{tabular}

to provide an initial estimate of $\mathrm{rCO}_{2}$ and the fractionated water loss. The energy expenditure can then be used to calculate the proportion of water loss undergoing fractionation $(\mathrm{X})$ and hence a revised estimate of energy expenditure and so on until there is no change with further iterations. Using this approach, we estimated the fractionated water loss, as a proportion of the total water loss, to be 0.42 (SE $0 \cdot 02$ ) (Table 4). This general approach may also be applied to other correction factors where there is enough information to estimate the parameter of interest from the basic data generated by the DLW method; i.e. $\mathrm{rCO}_{2}$ and $\mathrm{rH}_{2} \mathrm{O}$.

The stoichiometry of ${ }^{2} \mathrm{H}$ loss in the exchangeable and sequestered positions in sheep faeces has been estimated at $0 \cdot 12 \mathrm{~g}$ water equivalent per $\mathrm{g}$ faecal DM (Midwood et al. 1993). The faecal DM production can therefore be estimated from the DM intake and the digestibility of the diet. However, in order to calculate the DM intake it is necessary to know the composition of the diet and the level of energy expenditure. The assumption underpinning this approach is that the animals are in approximate energy balance. This seems reasonable given that there was no significant change in the mean body weight of the deer studied. This problem is similar to that for estimating $\mathrm{X}$ and can be approached in the same way. The metabolizable energy provided by the grass was estimated at $10 \cdot 22 \mathrm{MJ} / \mathrm{kg} \mathrm{DM}$ and the faecal DM production, measured in sheep consuming the same diet, at $0.41 \mathrm{~g}$ faecal $\mathrm{DM} / \mathrm{g} \mathrm{DM}$ intake. The total faecal DM production estimated this way, for the two-point flux data for example, was 965 (SE 47) g/d (Table 4).

It is known that some of the $\mathrm{H}$ in $\mathrm{CH}_{4}$ is derived from body water during methanogenesis (Czerkawski \& Breckenridge, 1974; Czerkawsi, 1975), therefore $\mathrm{CH}_{4}$ production provides a further route whereby the deuterium of body water may leave the body, leading to an overestimation of $\mathrm{rH}_{2} \mathrm{O}$ and an underestimation of $\mathrm{rCO}_{2}$. To calculate the effect of methanogenesis on the DLW method it is necessary to know the rate of $\mathrm{CH}_{4}$ production $\left(\mathrm{rCH}_{4}\right)$ and the stoichiometry of water $\mathrm{H}$ incorporation into $\mathrm{CH}_{4}$. Midwood et al. (1989) have shown that each litre of $\mathrm{CH}_{4}$ produced will cause $\mathrm{rH}_{2} \mathrm{O}$ to be overestimated by $1.052 \mathrm{~g}$ and $\mathrm{rCO}_{2}$ to be underestimated by 0.629 litres. These authors suggested that $\mathrm{rCH}_{4}$ may be calculated from an estimate of $\mathrm{rCO}_{2}$ since the $\mathrm{rCO}_{2}: \mathrm{rCH}_{4}$ ratio is relatively stable, falling between 10 and 20 for a wide range of animals fed at or above maintenance on very different diets with forage:concentrate ratios of 100:0 through to 20:80 (Midwood et al. 1989). For example, Brockway \& Maloiy (1967) measured an approximate $\mathrm{rCO}_{2}: \mathrm{CH}_{4}$ ratio of 16 in red deer consuming chopped hay. The exact ratio is mainly determined by the type of diet and level of intake and Midwood (1990) recorded a value of 13 in sheep consuming the same grass as that available to 
Table 3. Isotope distribution spaces and body composition in five red deer calculated by the multi-point and two-point methods (Individual values for five deer, with mean values and standard errors)

\begin{tabular}{|c|c|c|c|c|c|c|c|}
\hline Red deer... & A & $\mathrm{B}$ & C & $\mathrm{D}$ & $E$ & Mean & SE \\
\hline \multicolumn{8}{|c|}{ Multi-point method } \\
\hline $\mathrm{N}^{2} \mathrm{H}(\mathrm{kg})$ & $69 \cdot 49$ & $73 \cdot 43$ & $68 \cdot 66$ & $70 \cdot 19$ & $70 \cdot 49$ & $70 \cdot 45$ & $0 \cdot 81$ \\
\hline & $1 \cdot 02$ & $1 \cdot 46$ & $1 \cdot 76$ & 0.98 & $1 \cdot 13$ & $1 \cdot 27$ & $0 \cdot 15$ \\
\hline SE & 1.03 & $1 \cdot 60$ & 1.97 & 0.97 & $1 \cdot 19$ & 1.35 & $0 \cdot 19$ \\
\hline Ratio $\mathrm{N}^{2} \mathrm{H}: \mathrm{N}^{18} \mathrm{O}$ & $1 \cdot 033$ & 1.026 & 1.032 & $1 \cdot 022$ & 1.009 & 1.024 & 0.004 \\
\hline Isotopically estimated body water* (kg) & $66 \cdot 60$ & $70 \cdot 89$ & $65 \cdot 88$ & $67 \cdot 98$ & $69 \cdot 15$ & $68 \cdot 10$ & 0.90 \\
\hline SE & 0.58 & 0.56 & 0.53 & 0.65 & 0.58 & 0.58 & 0.02 \\
\hline $\mathrm{N}^{18} \mathrm{O}(\mathrm{kg})$ & 68.97 & $70 \cdot 45$ & $66 \cdot 19$ & $69 \cdot 48$ & $70 \cdot 98$ & $69 \cdot 21$ & 0.83 \\
\hline SE & 0.51 & 0.52 & 0.49 & 0.53 & 0.52 & 0.51 & 0.01 \\
\hline Ratio $\mathrm{N}^{2} \mathrm{H}: \mathrm{N}^{18} \mathrm{O}$ & $1 \cdot 030$ & $1 \cdot 023$ & 1.037 & $1 \cdot 018$ & $1 \cdot 018$ & 1.025 & 0.004 \\
\hline Isotopically estimated body water* (kg) & 68.29 & $69 \cdot 75$ & $65 \cdot 53$ & 68.79 & $70 \cdot 28$ & 68.53 & 0.83 \\
\hline
\end{tabular}

$\mathrm{N}^{18} \mathrm{O}$ and $\mathrm{N}^{2} \mathrm{H}$, isotope dilution spaces for ${ }^{18} \mathrm{O}$ and ${ }^{2} \mathrm{H}$ respectively.

${ }^{*}$ Body water $=\mathrm{N}^{18} \mathrm{O} / 1 \cdot 01$.

the deer in the present study. If we assume the same value of 13 for the red deer studied here it is possible to estimate the $\mathrm{CH}_{4}$ production from the $\mathrm{rCO}_{2}$ in an analogous way to the iterative procedure employed to derive a value for the fractionated water loss. The $\mathrm{CH}_{4}$ production so estimated was 93 (SE 5) litres/d (Table 4).

Energy expenditure in ruminant animals may be calculated from gas exchanges using the Brouwer equation (see Blaxter, 1989). However, this equation requires knowledge of $\mathrm{O}_{2}$ consumption $\left(\mathrm{rO}_{2}\right), \mathrm{rCH}_{4}$ and $\mathrm{N}$ loss in addition to $\mathrm{rCO}_{2}$. The value for $\mathrm{rCH}_{4}$ can be derived as described earlier and the $\mathrm{N}$ loss assumed to be equal to $\mathrm{N}$ intake, calculated from the $\mathrm{N}$ and energy contents of the diet and the estimated energy intake in these animals which were essentially weight stable.

With the raw isotope flux data, and the additional information generated, it is possible to calculate $\mathrm{rH}_{2} \mathrm{O}, \mathrm{rCO}_{2}$ and energy expenditure. A comparison of the multi-point and two-point methods showed no significant difference in any of these parameters (Table 5). For the multi-point approach the values were: $\mathrm{rH}_{2} \mathrm{O}, 11970$ ( $\left.\mathrm{SE} 543\right) \mathrm{g} / \mathrm{d}$; $\mathrm{rCO}_{2}, 1271$ (SE 40) litres/d; energy expenditure, $25 \cdot 23$ (SE 0.80) MJ/d. For the two-point approach the values were: $\mathrm{rH}_{2} \mathrm{O}, 11955$ (SE 723) $\mathrm{g} / \mathrm{d} ; \mathrm{rCO}_{2}, 1211$ (SE 59) litres/d; energy expenditure, $24 \cdot 05$ (SE 1.18) MJ/d. None of the differences was statistically significant.

The animals in the present study were given two isotopes of $\mathrm{H}$ (the stable isotope ${ }^{2} \mathrm{H}$ and the radio-isotope ${ }^{3} \mathrm{H}$ ) in order to calculate fractionated evaporative water loss as described elsewhere (Haggarty et al. 1988). The rationale behind this approach is that the isotope fractionation which occurs during evaporation is more pronounced for ${ }^{3} \mathrm{H}$ than ${ }^{2} \mathrm{H}$, therefore the difference in flux rates for ${ }^{3} \mathrm{H}$ and ${ }^{2} \mathrm{H}$ can be used to estimate the proportion of water loss which has undergone fractionation. However, two problems arise when using this approach. The first is that the difference between the ${ }^{3} \mathrm{H}$ and ${ }^{2} \mathrm{H}$ fluxes resulting from fractionation is relatively small. Taking the measured ${ }^{2} \mathrm{H}$ flux and an estimate of the expected ${ }^{3} \mathrm{H}$ flux for the fractionated water loss calculated by the iterative approach (X $0 \cdot 42)$, the difference between ${ }^{3} \mathrm{H}$ and ${ }^{2} \mathrm{H}$ flux would be approximately $95 \mathrm{~g} / \mathrm{d}$ (Table 6). The high value for $\mathrm{rH}_{2} \mathrm{O}$ in these animals (almost $12 \mathrm{~kg} / \mathrm{d}$ ) and the correspondingly high standard error on the flux rate estimates $\left(100 \mathrm{~g} / \mathrm{d}\right.$ for ${ }^{2} \mathrm{H}$, which

Table 4. Factors affecting the accuracy of the doubly-labelled water method for estimating energy expenditure in red deer* (Individual values for five deer, with mean values and standard errors)

\begin{tabular}{lccccccc}
\hline Red deer... & A & B & C & D & E & Mean & SE \\
\hline Fractionated water loss $(\mathrm{X})$ & $0 \cdot 41$ & $0 \cdot 43$ & $0 \cdot 45$ & $0 \cdot 46$ & $0 \cdot 34$ & $0 \cdot 42$ & 0.02 \\
$\mathrm{CH}_{4}$ production (litres/d) & 110 & 87 & 89 & 95 & 84 & 93 & 5 \\
Effect on $\mathrm{rH}_{2} \mathrm{O}$ (g/d) & 116 & 92 & 94 & 100 & 89 & 98 & 5 \\
Effect on $\mathrm{rCO}_{2}$ (litres/d) & -69 & -55 & -56 & -60 & -53 & -58 & 3 \\
Faecal $\mathrm{DM}(\mathrm{g} / \mathrm{d})$ & 1140 & 905 & 921 & 984 & 874 & 965 & 47 \\
Effect on $\mathrm{rH}_{2} \mathrm{O}$ (g/d) & 148 & 118 & 120 & 128 & 114 & 125 & 6 \\
Effect on $\mathrm{rCO}_{2}$ (litres/d) & -88 & -70 & -71 & -76 & -68 & -75 & 4 \\
Body-weight $\mathrm{Change}(\mathrm{g} / \mathrm{d})$ & 0 & -200 & -150 & 100 & 150 & -20 & 68 \\
Effect on $\mathrm{rH}_{2} \mathrm{O}$ (g/d) & 0 & 58 & 56 & -33 & -66 & 3 & 24 \\
Effect on $\mathrm{rCO}_{2}$ (litres/d) & 0 & 18 & 14 & -9 & -14 & 2 & 6 \\
\hline
\end{tabular}

$\mathrm{rH}_{2} \mathrm{O}$, water flux; $\mathrm{rCO}_{2}, \mathrm{CO}_{2}$ production.

*Based on flux rates derived from two-point data. Apart from fractionated water loss, the main factors affecting the doubly-labelled waterderived flux rate estimates in the deer studied here were $\mathrm{CH}_{4}$ production, faecal DM production and the change in body water associated with the small fluctuations in body weight. These are given here together with their effects on $\mathrm{rH}_{2} \mathrm{O}$ and $\mathrm{rCO}_{2}$. 
Table 5. Water flux, $\mathrm{CO}_{2}$ production and energy expenditure in red deer calculated by multi-point and two-point methods (Individual values for five deer, with means and standard errors)

\begin{tabular}{|c|c|c|c|c|c|c|c|}
\hline Red deer... & $A$ & B & C & $\mathrm{D}$ & $E$ & Mean & SE \\
\hline \multicolumn{8}{|c|}{ Mutli-point method } \\
\hline Water flux (g/d) & 13800 & 11006 & 11332 & 11087 & 12628 & 11970 & 543 \\
\hline SE & 174 & 203 & 332 & 150 & 189 & 210 & 32 \\
\hline $\mathrm{CO}_{2}$ production (litres/d) & 1415 & 1238 & 1177 & 1234 & 1290 & 1271 & 40 \\
\hline SE & 58 & 61 & 104 & 59 & 81 & 72 & 9 \\
\hline Energy expenditure (MJ/d) & 28.09 & $24 \cdot 58$ & $23 \cdot 36$ & $24 \cdot 49$ & $25 \cdot 60$ & $25 \cdot 23$ & $0 \cdot 80$ \\
\hline SE & $1 \cdot 30$ & $1 \cdot 38$ & $2 \cdot 34$ & $1 \cdot 32$ & $1 \cdot 82$ & $1 \cdot 63$ & 0.20 \\
\hline \multicolumn{8}{|c|}{ Two-point method } \\
\hline SE & $\begin{array}{r}14 \angle 49 \\
116\end{array}$ & $\begin{array}{r}10755 \\
84\end{array}$ & $\begin{array}{r}10019 \\
83\end{array}$ & 105 & $\begin{array}{r}1059 \\
106\end{array}$ & $\begin{array}{r}11955 \\
99\end{array}$ & $\begin{array}{r}123 \\
7\end{array}$ \\
\hline $\mathrm{CO}_{2}$ production (litres/d) & 1432 & 1136 & 1157 & 1236 & 1097 & 1211 & 59 \\
\hline $\mathrm{SE}$ & 104 & 77 & 77 & 90 & 95 & 89 & 5 \\
\hline Energy expenditure (MJ/d) & $28 \cdot 42$ & $22 \cdot 56$ & $22 \cdot 96$ & 24.53 & $21 \cdot 78$ & $24 \cdot 05$ & $1 \cdot 18$ \\
\hline SE & $2 \cdot 35$ & $1 \cdot 74$ & $\begin{array}{r}1 \cdot 74 \\
\end{array}$ & $2 \cdot 03$ & $2 \cdot 14$ & $2 \cdot 00$ & $0 \cdot 12$ \\
\hline Energy expenditure (\%) & \multicolumn{7}{|c|}{ Difference } \\
\hline
\end{tabular}

is measured by high precision mass spectrometry, and twice that $(200 \mathrm{~g} / \mathrm{d})$ for ${ }^{3} \mathrm{H}$ which is measured by scintillation counting with a lower precision) means that an expected difference of $95 \mathrm{~g} / \mathrm{d}$ could not be detected with this method at these water flux rates. Furthermore, ${ }^{3} \mathrm{H}$ and ${ }^{2} \mathrm{H}$ will undergo different degrees of fractionation during incorporation into $\mathrm{CH}_{4}$ and faeces, for example, but the isotope effects in these processes have not been quantified. Therefore, when there is significant production of $\mathrm{CH}_{4}$ and faecal $\mathrm{DM}$, as in ruminant animals, the methodology may be unreliable. For example, the additional water fluxes associated with $\mathrm{CH}_{4}$ and faeces production are 98 and $125 \mathrm{~g} / \mathrm{d}$ respectively. Therefore, a significant isotope discrimination effect between ${ }^{3} \mathrm{H}$ and ${ }^{2} \mathrm{H}$ in these processes would be enough to obscure the expected difference between ${ }^{3} \mathrm{H}$ and ${ }^{2} \mathrm{H}$ flux rates in these animals. Although the mean triply-labelled water derived value for $\mathrm{X}(0 \cdot 6)$ was close to the iteratively derived value of $0 \cdot 42$, the standard error was extremely high (2.04), primarily due to the poor precision of the $\mathrm{H}$ flux rate estimates. Thus, the value for $\mathrm{X}$ derived by iteration has been used here to calculate energy expenditure.

The calculation of energy expenditure from DLW data, as described here, requires the use of a number of stoichiometries and relationships derived in other studies and other species, therefore it is important to determine the sensitivity of the calculation to errors in these parameters. The results of a series of calculations of the percentage change in energy expenditure with changes in each of the parameters of interest are presented for deer A in Table 7. The value for each parameter in deer A, derived as described earlier, is assumed to produce the correct value $(0 \%$ error on energy expenditure). The percentage error in the calculated expenditure was determined for a range of values; it is worth noting that the relationship between energy expenditure and the parameters of interest was linear for all those studied with the exception of the $\mathrm{rCO}_{2}: \mathrm{rCH}_{4}$ ratio which produces a hyperbolic relationship when plotted against the error on energy expenditure. While the calculation of energy expenditure is relatively sensitive to the absolute amount of $\mathrm{CH}_{4}$ produced it is relatively insensitive to the $\mathrm{rCO}_{2}: \mathrm{rCH}_{4}$ ratio within the physiological range. Taking a range of values for the $\mathrm{rCO}_{2}: \mathrm{rCH}_{4}$ ratio, 10 through to 16 , which should cover most ruminant animals, the error on energy expenditure only ranged from $-0 \cdot 41$ to $+0 \cdot 24 \%$. The calculation of energy expenditure is also relatively insensitive to realistic variations in the digestibility of the diet and $\mathrm{N}$ loss. It is

Table 6. Calculation of fractionated water loss $(X)$ in red deer from ${ }^{3} \mathrm{H}$ and ${ }^{2} \mathrm{H}$ flux rates (Individual values for five red deer, with mean values and standard errors)

\begin{tabular}{|c|c|c|c|c|c|c|c|}
\hline Red deer... & $A$ & $\mathrm{~B}$ & C & $\mathrm{D}$ & E & Mean & SE \\
\hline $\begin{array}{l}N^{3} H(k g) \\
\text { Ratio } N^{2} H: N^{3} H \\
N^{3} H \text { flux }(g / d) \\
S E \\
N^{2} H \text { flux }(g / d) \\
\text { SE } \\
X \text { calculation from }{ }^{2} \mathrm{H} \text { and }{ }^{3} \mathrm{H} \text { fluxes }\end{array}$ & $\begin{array}{c}71 \cdot 73 \\
0.990 \\
14044 \\
332 \\
14159 \\
116 \\
0.42\end{array}$ & $\begin{array}{c}71 \cdot 11 \\
1 \cdot 014 \\
10262 \\
184 \\
10628 \\
84 \\
1 \cdot 65\end{array}$ & $\begin{array}{c}76 \cdot 43 \\
0 \cdot 898 \\
11474 \\
276 \\
10492 \\
83 \\
-7 \cdot 05\end{array}$ & $\begin{array}{c}64 \cdot 20 \\
1 \cdot 102 \\
10126 \\
130 \\
11047 \\
104 \\
3 \cdot 51\end{array}$ & $\begin{array}{c}54 \cdot 85 \\
1 \cdot 317 \\
11560 \\
94 \\
13056 \\
106 \\
4 \cdot 48\end{array}$ & $\begin{array}{c}67 \cdot 66 \\
1 \cdot 064 \\
11493 \\
203 \\
11876 \\
99 \\
0 \cdot 60\end{array}$ & $\begin{array}{l}3 \cdot 75 \\
0 \cdot 071 \\
703 \\
44 \\
734 \\
6 \\
2 \cdot 04\end{array}$ \\
\hline \multicolumn{8}{|c|}{ Calculation of expected ${ }^{3} \mathrm{H}$ flux using $\mathrm{X}$ derived from interation approach } \\
\hline \multicolumn{8}{|l|}{ Expected ${ }^{3} \mathrm{H}$} \\
\hline $\begin{array}{l}\text { flux for interative calculation of } X \\
\text { Expected difference }\left({ }^{2} \mathrm{H}-{ }^{3} \mathrm{H} \text { flux, } \mathrm{g} / \mathrm{d}\right)\end{array}$ & $\begin{array}{r}14046 \\
113\end{array}$ & $\begin{array}{r}10539 \\
89\end{array}$ & $\begin{array}{r}10401 \\
91\end{array}$ & $\begin{array}{r}10949 \\
98\end{array}$ & $\begin{array}{r}12970 \\
86\end{array}$ & $\begin{array}{r}11781 \\
95\end{array}$ & $\begin{array}{r}731 \\
5\end{array}$ \\
\hline
\end{tabular}

$\mathrm{N}^{2} \mathrm{H}$ and $\mathrm{N}^{3} \mathrm{H}$, isotope dilution spaces for ${ }^{2} \mathrm{H}$ and ${ }^{3} \mathrm{H}$ respectively; $\mathrm{X}$, fractionated water loss as a proportion of total water loss. 
Table 7. Sensitivity of energy expenditure to assumed stoichiometries, calculated using the doubly-labelled water-derived flux rates from animal $A$

\begin{tabular}{|c|c|c|c|}
\hline & Minimum & Assumed & Maximum \\
\hline$\overline{\mathrm{RQ}}$ & 0.900 & 0.941 & 1.000 \\
\hline Error on energy expenditure (\%) & $3 \cdot 78$ & 0.00 & $-4 \cdot 77$ \\
\hline Fractionated water loss $(\mathrm{X})$ & $0 \cdot 10$ & 0.41 & 0.50 \\
\hline Error on energy expenditure (\%) & $2 \cdot 37$ & 0.00 & -0.62 \\
\hline $\mathrm{rCH}_{4}$ (litres/d) & 50 & 110 & 150 \\
\hline Error on energy expenditure (\%) & 3.02 & 0.00 & $-1 \cdot 89$ \\
\hline Ratio $\mathrm{rCO}_{2}: \mathrm{rCH}_{4}$ & 10 & 13 & 16 \\
\hline Error on energy expenditure $(\%)^{*}$ & -0.41 & 0.00 & 0.24 \\
\hline Digestibility of diet & 0.50 & 0.59 & 0.60 \\
\hline Error on energy expenditure (\%) & $2 \cdot 05$ & 0.00 & $-0 \cdot 18$ \\
\hline $\mathrm{N}$ loss $(\mathrm{g} / \mathrm{d})$ & 200 & 245 & 300 \\
\hline Error on energy expenditure (\%) & 0.97 & 0.00 & -1.09 \\
\hline Specific heat capacity of water $(\mathrm{J} / \mathrm{g})$ & & $2 \cdot 418$ & $2 \cdot 447$ \\
\hline Error on energy expenditure (\%) & & 0.00 & $0 \cdot 14$ \\
\hline
\end{tabular}

$\mathrm{rCH}_{4}, \mathrm{CH}_{4}$ production; $\mathrm{rCO}_{2}, \mathrm{CO}_{2}$ production.

${ }^{*}$ Non-linear relationship between the ratio $\mathrm{rCO}_{2}: \mathrm{rCH}_{4}$ and energy expenditure.

slightly more sensitive to fractionated water loss although again, in this case, it is perhaps the energy required to evaporate water which is most relevant to a realistic estimate of the likely error. It can be seen that changing the value from that for evaporation at $33^{\circ}(2 \cdot 447 \mathrm{~kJ} / \mathrm{g})$ to that at $20^{\circ}(2 \cdot 418 \mathrm{~kJ} / \mathrm{g})$ (Blaxter, 1989) has a negligible effect on energy expenditure. Probably the single most important parameter in modulating energy expenditure is the RQ as a relatively small change from 0.900 to 1.000 can change the estimate of energy expenditure by almost $9 \%$. Estimation of the RQ is particularly problematic in animals which are growing or mobilizing body tissue as the RQ cannot simply be derived from the composition of the diet, it must also be adjusted for the composition of tissue gained or lost.

In this model the only parameters which were not derived but measured directly were the ${ }^{2} \mathrm{H}$ flux and ${ }^{18} \mathrm{O}$ flux. The animals studied were assumed to be in energy and material balance, therefore the RQ was obtained from the composition of the diet. For the derived parameters, it was necessary to know the previously measured stoichiometries and to set all the derived parameters either to zero or some initial approximation in the first cycle of iteration. However, even when some of the unknown parameters were initially set to zero, the convergence to the correct values for $\mathrm{rH}_{2} \mathrm{O}$, $\mathrm{rCO}_{2}$ and energy expenditure was very rapid; within only two iterations the values for $\mathrm{rH}_{2} \mathrm{O}, \mathrm{rCO}_{2}$ and energy expenditure had converged to within $0.05 \%$ of the value after ten iterations.

Failure to correct for sequestration would have resulted in a $5 \%$ underestimate because of $\mathrm{CH}_{4}$ production and a $6 \%$ underestimate because of faecal DM loss. Since these are cumulative the resulting error on the calculated energy expenditure would be $-11 \%$. However, it is already well established that it is necessary to correct for these processes, the issue is how well this can be done and the uncertainty which remains because of a lack of primary data. We have tried to estimate the parameters using an iterative approach and have evaluated the likely uncertainty on the calculation of $\mathrm{CO}_{2}$ production because of imprecise information on stoichiometries etc. (Table 7). Given realistic estimates of these parameters we expect the greatest uncertainty to come from the estimate of RQ then $\mathrm{CH}_{4}$ production then fractionated water loss, with likely uncertainties in the other parameters accounting for only a few percent. The choice of parameters to include in the iteration procedure largely depends on how good the initial estimates of unmeasured parameters are. Thus, the results in Table 7 indicate that the initial estimates of parameters such as the $\mathrm{rCO}_{2}: \mathrm{rCH}_{4}$ ratio, or the digestibility of the diet, or the specific heat capacity of water were sufficiently good that they could have been fixed, and therefore removed from the iteration process, without much loss of accuracy. However, care needs to be taken that inconsistencies are not introduced by fixing parameters which should be allowed to vary when setting up this type of model. For example, the $\mathrm{N}$ loss will depend on the energy intake and hence energy expenditure and therefore should be allowed to vary with energy expenditure.

\section{Conclusions}

The energy requirements of deer at pasture cannot be readily predicted from measurements made indoors because of the additional demands of muscular activity and thermoregulatory thermogenesis in free-living animals. An illustration of the effect of such additional demands can be seen by comparing the feeding studies of Fennessy et al. (1980), who estimated the energy requirement of red deer stags fed outdoors in winter at $850 \mathrm{~kJ} / \mathrm{kg}^{0.75}$ per d, with feeding studies of red deer stags penned indoors (Key et al. 1984) where the estimated energy requirement was $570 \mathrm{~kJ} / \mathrm{kg}^{0.75}$ per d. Unfortunately, outdoor feeding studies of this type are difficult to carry out, as indicated by the small number of such reports, and they inevitably interfere with normal behaviour such as foraging. It has, therefore, been necessary to develop alternative approaches to estimating energy expenditure in free-living animals and the most promising of these is the DLW method (Lifson \& McClintock, 1996). However, this method only provides an estimate for $\mathrm{rCO}_{2}$, therefore additional information on $\mathrm{O}_{2}$ consumption, $\mathrm{N}$ loss and, in the case of ruminants, $\mathrm{CH}_{4}$ production, is required to calculate a value for energy expenditure. We have proposed here an approach to calculation where, after an initial approximation, each parameter is repeatedly calculated until there is no change with further iteration. In practice, the convergence to stable values occurs within only a few cycles of iteration and the accuracy of the final estimates depends only on the accuracy of the stoichiometries of the relationships between the parameters of interest and knowledge of external factors such as the composition of the diet. Analysis of the sensitivity of this approach to errors in the parameters and stoichiometries indicates that, with the exception of the RQ, the approach is relatively insensitive to likely physiological variations in the parameters used.

The two approaches to sampling used in DLW studies, multi-point and two-point were compared. The animals studied here were accustomed to handling and could be sampled relatively easily every day. However, this would not be the case in animals ranging freely over rough pasture. Furthermore, daily capture and sampling could, in itself, significantly affect the energy expenditure of free-ranging animals. In such animals, the two-point methodology, where 
body fluids are sampled only at the beginning and end of an experiment, typically lasting between 1 and 2 weeks, would be a more feasible approach. A comparison of multi-point and two-point calculations showed that there was no significant difference in the energy expenditure derived by these approaches in the animals studied here. Apart from the advantage of minimal interference with normal behaviour, the two-point method also has the advantage that the estimate of precision does not include a term for daily variation in $\mathrm{rH}_{2} \mathrm{O}$ and $\mathrm{rCO}_{2}$. Such daily variation is not usually of interest in DLW studies but the multi-point approach necessarily includes this term in the equivalent estimate of precision.

The estimate of precision on the value for energy expenditure for each animal is useful for between-animal comparisons. For example, it allows us to identify that the oldest animal studied here had a significantly higher level of expenditure than the others despite having the lowest body weight. Since all the animals were exposed to the same mild climate, this difference was presumably due to a higher physical activity, possibly reflecting the dominance of this hind within the social group. No study was made of social interactions in these animals but this observation illustrates how the DLW method may provide information in addition to the estimation of energy requirements of groups.

The practical advantages afforded by the two-point method over the multi-point method make this by far the easiest method to use and the only feasible method for use in truly free ranging animals. Given that there was no significant difference in the results obtained using these two approaches it would appear that the two-point methodology may be used with confidence in such animals. The main advantage of the multi-point method is that the possibility of bias due to an unreliable sample or analysis is minimized by the averaging effect of large numbers of samples. This is not so important that it would over-ride the advantages of the two-point methodology in free-ranging animals but, where both approaches have been used, the multi-point method is likely to produce the better estimate of energy expenditure. Using the data from the multi-point calculation we estimate that the energy expenditure of the red deer studied here (mean body weight $107 \mathrm{~kg}$ ) was $25 \mathrm{MJ} / \mathrm{d}$. This is $20 \%$ higher than the value of $21 \mathrm{MJ} / \mathrm{d}$ recommended for adult red deer hinds kept outdoors (Adam, 1986) and, at $757 \mathrm{~kJ} /$ $\mathrm{kg}^{0.75}$ per d, a third higher than the value of $570 \mathrm{~kJ} / \mathrm{kg}^{0.75}$ per $\mathrm{d}$ for stags penned indoors (Key et al. 1984). These values for energy expenditure are probably realistic for hinds in typical lowland farming conditions in summer. Energy expenditure in winter may be higher because of the physical activity associated with foraging over rough terrain or it may be reduced because of reduced diet-induced thermogenesis associated with reduced food intake and an adaptive reduction in physical activity as a strategy to increase the efficiency of utilization of available food. The ambient temperature during the summer experimental period (maximum of $16 \cdot 6^{\circ}$, minimum of $9 \cdot 5^{\circ}$, with little wind) should represent a minimal thermal stress to red deer, therefore it seems unlikely that thermoregulatory thermogenesis would account for much of the difference between stags penned indoors and the hinds studied outdoors. That leaves the energy cost of physical activity. Anderson (1976) has proposed that even in freely-ranging deer, normal movements about the hill would probably increase energy requirements by only 10-20\% above those of the stationary animal. However, when compared with the value for stags penned indoors, the results presented here for animals kept in a relatively small, lowland paddock, suggest an increase of about $33 \%$. Where animals have to forage over large areas to obtain sufficient intake of a poorer quality diet the energy cost of physical activity may be considerably higher. Similarly, more extreme weather conditions could further increase the energy requirements of the animals studied here under mild summer conditions. By using the sampling and methodological approaches described here, the DLW method could provide estimates of the energy requirements of red deer under more extreme conditions.

\section{Acknowledgement}

The authors wish to thank The Scottish Office Agriculture, Environment, and Fisheries Department who provided financial support for this work.

\section{References}

Adam CL (1986) Nutrition of deer. Deer Farming 14, 6-19.

Anderson JEM (1976) Food energy requirements of wild Scottish red deer. In Red Deer in South Ross, pp. 170-178 [WES Mutch, JD Lockie and AB Cooper, editors]. Edinburgh: University of Edinburgh.

Blaxter K (1989) Energy exchanges by radiation, convection, conduction and evaporation. In Energy Metabolism in Animals and Man, pp. 86-119. Cambridge: Cambridge University Press.

Brockway JM \& Maloiy GMO (1967) Energy metabolism of the red deer. Journal of Physiology, London 194, 22P-24P.

Czerkawski JW (1975) Some stoichiometric relations and their value in rumen studies. In Tracer Studies on Non-Protein Nitrogen for Ruminants, pp. 53-63. Vienna: International Atomic Energy Agency.

Czerkawski JW \& Breckenridge G (1974) Use of tritiated compounds in the study of methanogenesis. Proceedings of the Nutrition Society 33, 76A-77A.

Fancy SG, Blanchard JM, Holleman DF, Kokjer KJ \& White RG (1986) Validation of doubly labelled water method using a ruminant. American Journal of Physiology 251, R143-R149.

Fennessy PF, Greer GJ \& Forss DA (1980) Energy requirements of red deer. Proceedings of the New Zealand Society of Animal Production 41, 167-173.

Haggarty P (1990) The effect of isotope sequestration and exchange. In I.D.E.C.G. Report. The Doubly Labelled Water Method for Measuring Energy Expenditure. Technical Recommendations for Use in Humans, pp. 114-116 [AM Prentice, editor]. Vienna: International Atomic Energy Agency.

Haggarty P (1991) The potential of the doubly labelled water method for estimating heat production in farm animals. Journal of Agricultural Science 117, 141-148.

Haggarty P, Franklin MF, Fuller MF, MacGaw BA, Christie SL, Milne E, Duncan G \& Smith JS (1994a) Validation of the doubly labelled water method in growing pigs. American Journal of Physiology 267, R1574-R1588.

Haggarty P, McGaw BA \& Franklin MF (1988) Measurement of fractionated water loss and $\mathrm{CO}_{2}$ production using triply labelled water. Journal of Theoretical Biology 134, 291-308.

Haggarty P, McGaw BA, Fuller MF, Christie SL \& Wong WW (1990) Water hydrogen incorporation into body fat in growing 
pigs; its effect on the double and triple labelled water methods. American Journal of Physiology 260, R627-R634.

Haggarty P, McNeill G, Abu Manneh MK, Davidson L, Milne E, Duncan G \& Ashton J (1994b) The influence of exercise on the energy requirements of adult males in the UK. British Journal of Nutrition 72, 799-813.

Johnson KG, Maloiy GMO \& Bligh J (1972) Sweat gland function in the red deer (Cervus elaphus). American Journal of Physiology 223, 604-607.

Key RNB, Milne JA \& Hamilton WJ (1984) Nutrition of red deer for meat production. Proceedings of the Royal Society of Edinburgh 82B, 231-242.

Lifson N \& McClintock R (1966) Theory of use of the turnover rates of body water for measuring energy and material balance. Journal of Theoretical Biology 12, 46-74.

Midwood AJ (1990) Application of the doubly labelled water technique for measuring $\mathrm{CO}_{2}$ production to sheep. $\mathrm{PhD}$ Thesis, University of Aberdeen.

Midwood AJ, Haggarty P \& McGaw BA (1993) The doubly labelled water method; errors due to deuterium exchange and sequestration in ruminants. American Journal of Physiology 264, R561-R567.

Midwood AJ, Haggarty P, McGaw BA, Mollison GS, Milne E \& Duncan GJ (1994) Validation in sheep of the doubly labeled water method for estimating $\mathrm{CO}_{2}$ production. American Journal of Physiology 266, R169-R179.

Midwood AJ, Haggarty P, McGaw BA \& Robinson JJ (1989) Methane production in ruminants: its effect on the doubly labeled water method. American Journal of Physiology 257, R1488-R1495.

Midwood AJ, Haggarty P, Milne E \& McGaw BA (1992) Factors affecting the analysis of ${ }^{18} \mathrm{O}$-enriched aqueous samples when using $\mathrm{CO}_{2}$ equilibration in vacutainers. Applied Radiation and Isotopes 43, 1341-1347.

Wong WW, Lee L \& Klein PD (1987) Deuterium and oxygen-18 measurements on microliter samples of urine, plasma, saliva and human milk. American Journal of Clinical Nutrition 45, 905913. 